\title{
Learning Strategy for Students' Entrepreneurial Spirit through Students' Cooperation (KOPMA)
}

\author{
Meiwatizal Trihastuti' ${ }^{1}$ Aim Abdulkarim ${ }^{2}$, Endang Danial ${ }^{3}$, Acep Supriadi ${ }^{4}$ \\ Universitas Pendidikan Indonesia, Indonesia
}

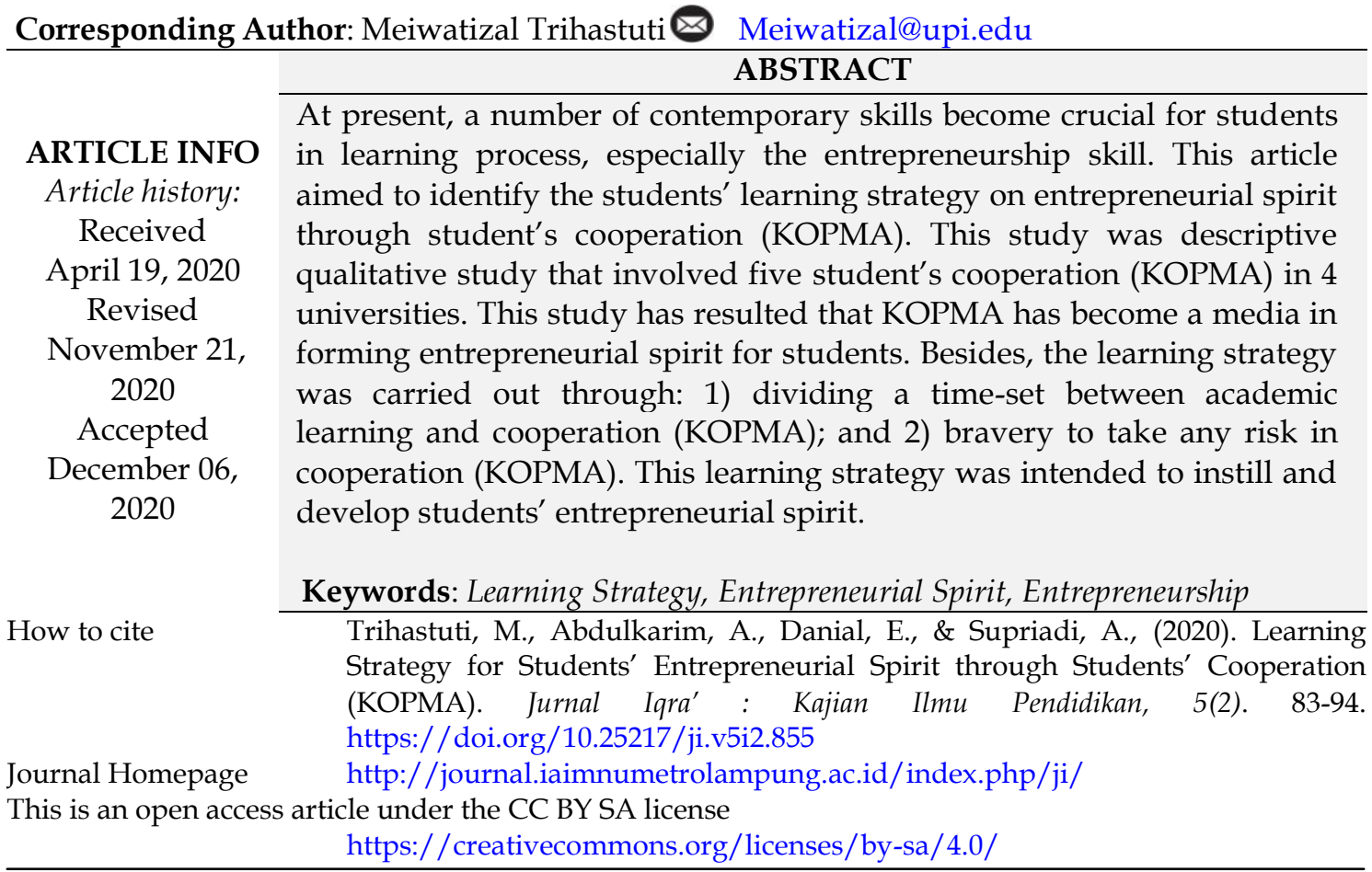

\section{INTRODUCTION}

Learning strategies are the ways of individuals organize and use a certain set of skills to learn content or complete other tasks more effectively and efficiently in school and in non-academic environment. Learning strategies play a role in gaining success in students (Neroni et al., 2019). At present, various skills become crucial for students to master during their learning process, especially entrepreneurship skills. Anggraeni \& Nurcaya (2016) say that fostering an entrepreneurial spirit has become an alternative in overcoming limited job opportunities and reducing unemployment. Thus, a mastery of entrepreneurial skills for students requires an effective way in the process of students' learning. In students' cooperation, the teaching objectives and the preparation of plans to achieve the objectives, and the preparation of instructional plans related to the entrepreneurial spirit have been systematically arranged. A research on the factors that influence the choice to enter or exit from entrepreneurship career, has resulted that the application of a structured model can help career counselors, college career centers, placement companies, and other vocational advisors in guiding students and communities in determining entrepreneurial careers (Callanan \& Zimmerman, 2016).

At least, students who want to be an entrepreneur must have an entrepreneurial spirit. Fini \& Toschi's (2015) research on the extent to which corporate entrepreneurial intentions are treated differently (for academic and non-academic entrepreneur), have showed that academic entrepreneur can significantly increase 
students' awareness on technical competence, and that the entrepreneurial self-efficacy and awareness of managerial skills are far less. Being an entrepreneur is to realize an innovative idea, so that the creation of capital and resources must also be a part to reconsider in the willingness of being an entrepreneur. Manimala, Thomas, \& Thomas (2019) explain that the entrepreneurial ecosystem is an interacting socioeconomic environment that facilitates entrepreneurs to start and develop their business. A vibrant and supportive entrepreneurial ecosystem is required to start and grow up a company. In addition, Rimadani \& Murniawaty's (2019) research on entrepreneurship has also addressed school level to determine the partially and simultaneously effect between entrepreneurship education, business center and creativity on the spirit of entrepreneurship. The results has showed that the effect of entrepreneurship education on entrepreneurial spirit was $8.24 \%$, the effect of business center on entrepreneurial spirit was $31.58 \%$, the effect of creativity on entrepreneurial spirit was $10.3 \%$ and the effect of entrepreneurship education, business center and creativity on the soul entrepreneurship $65.8 \%$. By these results, it can be clearly spoken that entrepreneurship is about a belief to change the world through ideas and innovations, and courage is the main key in the realization of entrepreneurship.

The entrepreneurship is a key to achieve national independence. Entrepreneurship shows national independence (Nagel, 2017). People who have an entrepreneurial spirit are entrepreneurs. Nevertheless, Ningrum (2017) explains that the entrepreneurial spirit cannot be obtained instantly and in a short time. The main asset or capital to be a successful entrepreneur is a strong motivation within individuals themselves as well as courage in taking risks, perseverance and persistence in running their business, so as to make entrepreneurs strong and not easily discouraged. Almodóvar-González et al., (2020) identify factors about entrepreneurial enthusiasm and economic growth. The results suggest that entrepreneurial activities play different roles depending on the economic stage of the country concerned. On the other hand, less developed countries should not be based on generic entrepreneurship if the goal they pursue is to encourage economic growth. Bogatyreva et al., (2019) conceptualizing entrepreneurial actions as intentional, goal-oriented behavior, driven primarily by entrepreneurial intentions. Using data from two waves of multi-country Studies (GUESSS), found that core aspects of national culture influence the relationship between entrepreneurial intentions and subsequent actions. In adition, Vladasel, Lindquist, Sol, \& van Praag, (2020) from the consensus that entrepreneurship runs in families from Swedish data registers using the theory of human resource formation to state that family and society provide a prominent context for the development of individual entrepreneurial skills and preferences. The intensity of human and financial capital that is higher than that combined relative to unrelated entrepreneurship is predicted to change the hierarchy of family influence. Martin-Rojas et al., (2019) analyze how management support for technology and technology skills enables influencing organizational performance through corporate entrepreneurship, by conducting a Structural Equation Model analysis with a sample of 201 Spanish technology companies. The results show that awareness of technological problems enables entrepreneurship in companies. Holcomb et al., (2009) have extended the existing entrepreneurial learning theories and highlighting the effects of heuristics under two different learning contexts that resulted in linkages between heuristics, knowledge, and action as well as to test the effect of assessment on learning and to expose conditions that can benefit or limit effective action in an entrepreneurial environment. 
Considering the previous description, this study a focus on the identification of learning strategy form on the entrepreneurial spirit through student cooperation. The variables of this research are learning strategy and entrepreneurial spirit. This study is expected to contribute theoretically to the renewal of Citizenship Education studies in the realm of civic entrepreneurship. The practical benefit is to add insight and direct experience of learning the entrepreneurial spirit through student cooperation.

\section{METHOD}

This study used descriptive qualitative design. Bogdan and Taylor argued that qualitative was a research procedure that produced descriptive data in the form of words (Moleong, 2007). This study was limited on factors that influenced the spirit of entrepreneurship through student's cooperation (KOPMA) that consisted of two keys: cooperation as a) a place of practice; and b) as entrepreneurial environment. Researchers collect data using interviews, observation and documentation. Interview researchers conducted for 30-40 minutes to the informant. The location of the interview is in the secretariat of student's cooperation (KOPMA) or according to the informant agreement. Researchers use a recording tool to record interviews so that no data is missed. This study involved 5 student's cooperation in 5 universities in Bandung, namely: 1) student's cooperation at Indonesia Education University; 2) student's cooperation at Islamic University of Bandung; 3) student's cooperation at Institute for Technology Bandung; 4) student's cooperation at Pasundan University; and 5) student's cooperation at Padjadjaran University.

The data were analyzed by using Miles and Huberman principle, namely: data reduction, data display, and making conclusion or verification (Usman \& Akbar, 2009). The sampling was performed by using purposive sampling based on some criteria, namely: 1) student; 2) registered as member of student's cooperation (KOPMA); 3) being a member of student's cooperation (KOPMA) for more than 3 months; AND 4) being active in the activities by students' cooperation (KOPMA). The instrument of this study was interview draft, observation sheet, and documentation. To validate the data, this study used credibility criteria; that was investigation persistence. Sugiyono (2010) argued that this model of credibility of criteria has a mean to conduct an observation and investigation in accurate and continuity. Therefore, this study limited the discussion on learning strategy on entrepreneurial spirit through student's cooperation.

\section{RESULT AND DISCUSSION}

The result of this study was divided into two sections, namely 1) the forming of entrepreneurial spirit through student's cooperation was reinforced and encouraged by the availability of trainings in student's cooperation (KOPMA); and 2) there was a learning strategy to form entrepreneurial spirit for students. With respect to the identity of the informants, the researchers of this study would use their initials when describing the result of the interview on the informants.

\section{The Forming of the Entrepreneurial Spirit through Student Cooperatives}

Student cooperation has become a place in the forming of students' entrepreneurial spirit. Being an entrepreneur is a step to achieve a success. Student's cooperation factually bring a number of benefits for students. 
Figure 1: The benefit of student's cooperation|for students themselves

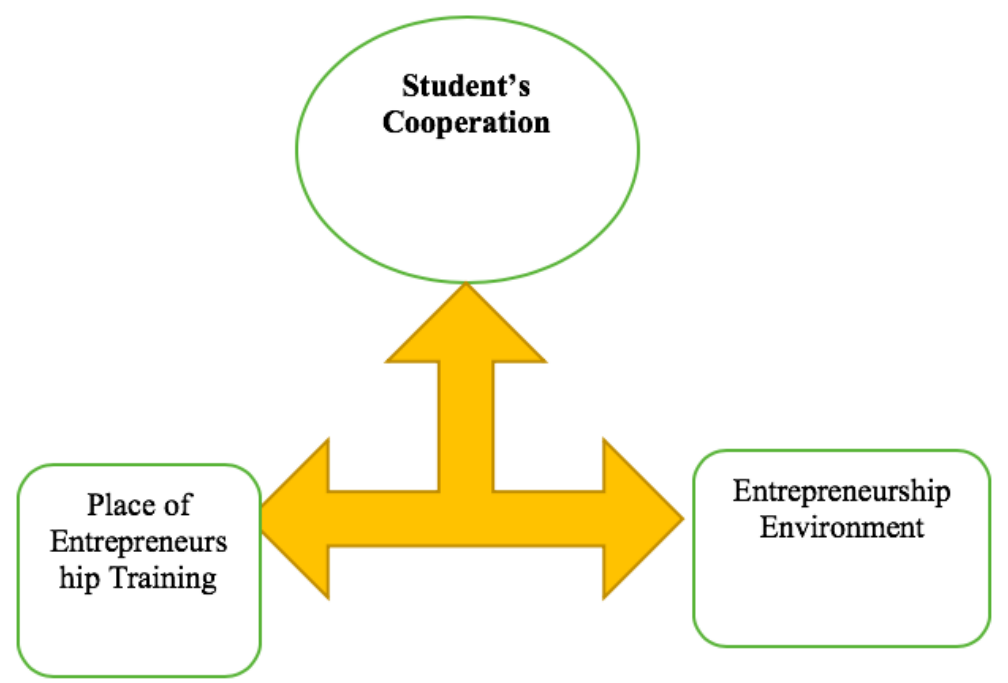

Source: Research Data, 2020

Based on figure 1, to be an entrepreneur, everyone can be influenced by many factors, namely education, family, environment, friend, and so on. Phonthanukitithaworn, Ketkaew, \& Naruetharadhol (2019) research that studied the successful factors of an online entrepreneur in Bangkok, Thailand showed that thirteen of the most relevant factors related to online entrepreneurs were ACO, EOU, government support, networks, risk-taking tendencies, reliability, AFF, BIM, logistics and transportation, quality products, product prices, advertisements on social media, and staff and employees.

In addition, being an entrepreneur can also be influenced by individual and environmental factor. However, the existence of an environment where there is an entrepreneurial atmosphere is believed to be a driving factor. It tell About the antecedents and the results of the aspirations of the entrepreneurial identity. Farmer, Yao, \& Kung- Mcintyre (2011) argued that based on three samples from the perspective of self-identity, a model was drawn to describe the antecedents and results of aspirations of entrepreneurial identity. In two of the three samples, the strength of the aspirations of entrepreneurial identity was significantly related to the extent to which an individual's self-description corresponded to perceptions about the role of entrepreneur. However, the power of identity aspirations predicted the behavior of discovery and exploitation in all three samples. However, entrepreneurship is also related to self-potential, and that the entrepreneurial potential will be fertile if it continues to be developed.

Entrepreneurship and the establishment of new enterprise are seen as important drivers for the change and renewal of media industry. However, whether a newly established company will emerge in the future, and it depends to a large extent on the individual entrepreneur. Similar to this, a study conducted a survey on students from 47 universities in Germany $(\mathrm{N}=720)$, and identified important factors that explained the entrepreneurial intentions of today's mass communication students, who were likely to become one of the future novice founders in the journalism and media industry. The conclusions of the study has indicated the possibility of early 
identification of potential media for entrepreneurs and their continued encouragement by journalism and mass communication educators (Buschow \& Laugemann, 2020).

Based on the results of interview with SE, a member of student's cooperation (KOPMA) at Padjajaran University has resulted that the formation of an entrepreneurial spirit through student cooperation received an intake from the existing student cooperation (KOPMA) activities. The intake included basic and advanced training. In line with SE, ERF as a member of student's cooperation (KOPMA) at Bandung Institute of Technology argued that student's cooperation is a forum for them to express their entrepreneurial spirit, because the formation of an entrepreneurial spirit through student's cooperation required a place to practice. In this context, Arumugam \& Sankaranarayanan's (1992) research on the development of twenty five years old entrepreneurs in India, has produced that the role of a training was to attract trainees, provided advice and organized assistance for entrepreneurs whom were trained together with organizations supporting entrepreneurial development until participants has become successful entrepreneurs. Growing an entrepreneurial spirit and jumping into building a business are the initial steps for a person to become an entrepreneur and the presence of a student cooperative can be a facilitator in the student's initial steps.

New entrepreneur often experiences a large number of professional pressure caused by their work activities (Omrane, Kammoun, \& Seaman, 2018). Many people start to be an independent enterprise, because they can take an advantage of the opportunities they get in their environment. Ozturkcan, \& Gur (2019) explain that the main role of competing life, work and family, has reportedly dominated the efforts of people in building their lives. Meanwhile, most scholars who study entrepreneurship have given a great and positive value by exploring the factors that explain how entrepreneurs create new business and how society and the economy can grow and develop (Thornton, Ribeiro-Soriano, \& Urbano, 2011). Based on an observation on student's cooperation (KOPMA) at Pasundan University, it was found that the students were very solid in progressing student's cooperation (KOPMA), so that a kinship atmosphere was very thick and became a certain condition. This condition can make and foster student's cooperation (KOPMA) to be a comfortable place for them.

A study on the interrelationship between embeddedness and second generation entrepreneurs in Vietnam, has identified four causal relations between inherent activities and entrepreneurship, namely: (a) resource mobilization; (b) the formation of entrepreneurial motivations; (c) the effect of feedback on embeddedness; and (d) the re-establishment of multiple identities. This research factually has contributed to research on ethnic entrepreneurship by showing a new causal relationship between socio-psychological factor and entrepreneurial activities of second generation entrepreneurs (Dang \& Harima, 2020). Relevant to this study, the result of interview with member of student's cooperation (KOPMA) at Indonesian Education University has indicated that they still maintain relationships with previous management as to maintain the stability of student's cooperation at Indonesian Education University.

The choices made by an entrepreneur at various stages of business development are key elements of entrepreneurship that contribute to entrepreneurial success (Panda, 2000). The results of interview with a student at Islamic University of Bandung, found that there was cooperation to be able to develop businesses, such as profit-sharing or cooperation with other parties. Yun \& Park's (2016) study on economic innovation has asserted that user's innovation is a new economic paradigm that has an ability to create new mechanism for social and economic development. 
High motivation to do a business will foster an entrepreneurial spirit in it. To overcome the search for capital or development, everyone should find out a working space and start to work seriously.

\section{Students' Learning Strategy in Forming an Entrepreneurial Spirit}

Forming an entrepreneurial spirit requires number of strategies as consideration, especially for students who face various conditions in the rhythm of their academic lives. Jayawarna, Rouse, \& Kitching (2011) have proposed two conceptual developments in understanding entrepreneurial motivation and its effects. Firstly, the entrepreneurial motivation develops dynamically in its relation to career, household and business life courses. Secondly, making a concept of how motivation and life courses can develop interactively.

Based on the result of interview with $\mathrm{AD}$ as a member of student cooperation (KOPMA) at Pasundan University, has indicated that their learning strategy in forming and establishing the entrepreneurial spirit was to set goals and instructional planning skills. Relevant to this result, a survey on 360 novice entrepreneurs who have been supported by a mentor, showed a direct effect of mentoring on entrepreneurial selfefficacy which mediated the relationship between satisfaction of being an entrepreneur and the intention to remain in the profession. In addition, mentoring does not only have an indirect effect on satisfaction, but also seems to have a direct negative effect on intention (St-Jean \& Mathieu, 2015). The possession of skills in classroom management in the strategy of forming an entrepreneurial spirit is required to be an active media that can produce positive knowledge for students.

On the other hand, a research in Africa on social capital (SC) was said as an important resource for informal economic (Kebede, 2018). In learning strategy in term of forming entrepreneurial spirit, students will face many obstacles and challenges when starting an enterprise. The results of interview with AP as a member student's cooperation (KOPMA) at Islamic University of Bandung has indicated that learning strategy (in forming the spirit of entrepreneurship) was focused for self-discipline to be consistent for students at student cooperation (KOPMA). In this case, Ciuchta, Letwin, Stevenson, McMahon, \& Huvaj (2017) argue that the ability to train entrepreneurship is a decent signal in the setting of entrepreneurial training experience. The ability to divide time and determine goals in student cooperation (KOPMA) is an important element in the process of forming an entrepreneurial spirit.

A research on the understanding of entrepreneurial relationship between Pakistani and Western entrepreneurs, has resulted that political instability appeared as a major trial faced by most entrepreneurs; which in-turn caused reluctance, reliability, and trust issues among foreign investors (Pervaiz \& Khan, 2015). Another analysis with autobiographical narrative method in the constructivist paradigm to explore the phenomenon of autonomy has resulted that this kind of relationship promoted the loss of entrepreneurial capacity. The finding was important for better understanding of support for entrepreneur (Albert \& Couture, 2013). In connection with the learning strategy of students in forming an entrepreneurial spirit, a form of self-autonomy is to set some goals in student cooperation (KOPMA).

On the other hand, a study on the impact of entrepreneurial demographic characteristics (age, experience and education), entrepreneurial network structure (size, density and centrality), type of entrepreneurial network (competitive and supportive) and entrepreneurial self-efficacy on subjective performance of 148 micro and small enterprise in the textile and handicraft group handloom in Kutch, Gujarat, India by 
using regression analysis has shown that size, density, centrality, entrepreneurial selfefficacy, competitive and supportive networks significantly predicted subjective performance by 56 percent of the variance in the dependent variable (Prajapati \& Biswas, 2011). Many people postpone and reason not to start a business, whereas their dream is to have a business without any action. Srinath \& Supriya (2009) convey that certain personal characteristics, backgrounds, motivations, and goals factually distinguish between types of entrepreneurs.

Entrepreneurship is known as a demanding activity with increasing workload, financial uncertainty, and increasing stress levels (Dahl, Nielsen, \& Mojtabai, 2010). The result of interview with a member of student cooperation (KOPMA) at Padjadjaran University, has resulted that they apply their self-control, as not to stress out within their activities at student cooperation (KOPMA). Relevant to this, a research on the factors that influence entrepreneurial intention through correlation between cognitive factors and perceived environmental perception, has shown that the effect of one's perceived ability to become an entrepreneur on the intention to engage in such behavior depended on environmental perception that was rich for entrepreneurial luxury (incubator environment). The perception on entrepreneurship is also helpful to strengthen the relationship between risk-taking tendencies and entrepreneurial selfefficacy (Bacq, Ofstein, Kickul, \& Gundry, 2016). Meanwhile, a study that investigated the context (when, how and why) of students in exploiting an opportunity of management behavior (cause-effect, influence and bricolage) in fundraising projects as microcosms of the entrepreneurial world, has shown that opportunity of management theory must take a more prominent role in the entrepreneurship curriculum in higher education (Chang \& Rieple, 2018).

Based on previous discussion, the result of this study indicated that KOPMA has become one of media in the forming of entrepreneurship for students. Relevant to this, a study has also resulted that cooperation helped to overcome students' learning to improve the quality of education as relevance to enterprise world (Zulaihati \& Susanti, 2018). Furthermore, a conceptual study has also resulted that cooperation was one of media to open any change in working space as decreasing unemployment (Abd Majid, Zainol, Norhayate, \& Afthanorhan, 2019). In addition, a study on the rate of students' interest to be a member of the cooperation (KOPMA) was significant as it was influenced by three factors, namely knowledge on KOPMA, benefit of KOPMA, and cooperation subject (Kusumantoro, 2010). Therefore, this study has become a contribution as one of media to form entrepreneurship character for students. The objective was to extent value of citizenship pedagogy manifested in the form of attitude and characteristics as good citizens.

Besides, another study has also indicated that the strategy of learning was conducted through dividing a time sequence between academic learning and cooperation (KOPMA). Similarly, a study has also reported that a calculation in the development of entrepreneurship character of the members with $58.22 \%$ and approximately $41 \%$ - 60\%. It signified that student's cooperation (KOPMA) has a sufficient role in developing its members entrepreneurship character (SARI, 2010)

Furthermore, a study has categorized three categories of individual's readiness in entrepreneurship, namely sociology, psychology, and entrepreneurship management (Coduras, Saiz-Alvarez, \& Ruiz, 2016). A study o of Aini in 2017 has discovered that 82.7\% of KOPMA's member participation was influenced by cooperation education, effective contribution of cooperation education was $23,9 \%$, cooperation service was $6,4 \%$, cooperation motivation was $31,1 \%$, member satisfaction was $2,0 \%$, member's 
degree of trust was $14,1 \%$, and entrepeneurship environment was 5,3\% against their participation (Aini, 2017). Therefore, time management between the academic and cooperation activities has contributed to this study and expected to recognize that KOPMA has become a media in teaching students to manage their times. Besides, the contribution of this study is also expected to give a certain contribution on civic enterpreneursip in Citizenship Education as well as identifying that KOPMA has become a part of civic community. Furthermore, this study also resulted that the strategy of learning in the forming of entrepreneurship character for students is a bravery and commitment in taking a risk in KOPMA. As a response to it, a study has suggested students to develop interpersonal competence, social, and team work that can determine professional and social success (Mendo-Lázaro, León-Del-Barco, FelipeCastaño, Polo-Del-Río, \& Iglesias-Gallego, 2018). It also found that social competence for team work was included in a bravery or commitment to take a risk in KOPMA

Another phenomenon of cooperation was also found in KOPMA UGM that the KOPMA could awaken students' entrepreneurship spirit. The study has also found that the KOPMA UGM has presented a good performance on public and be able to work together and have a role in the economic sustainability (Malaya, Suprihanto, \& Kodiran, 2015). A study by Lackeus has found that students were motivated and involved in KOPMA by creating entrepreneurship values and risk-taking in education sector (Lackéus, 2015). Another study also stated in similar that the use of STAD learning model for students" entrepreneurship character development was proper for the stakeholders themselves (Munawaroh, 2013).

In addition, the result of a study on Mexican education has proven the important role of teachers in the development of entrepreneurship competence as well as business values (Cárcamo-Solís, 2017). Another study has also suggested that the experience in KOPMA has assisted students in fostering their education, particularly the 21th century education (Zimnoch, 2018). Therefore, learning strategy performed to develop students" entrepreneurship character is a bravery to take a risk in team work. Besides, KOPMA can also form values of entrepreneurship with a bravery to take a risk. This statement of the study implicates to build and construct a positive discourse on cooperation movement which is oriented to the acknowledgment and understanding of cooperation concept and civic enterpreneuship.

In deed, an entrepreneur must have a courage to act and allay his fears to enter the business. A research by Estrada Cruz, VerdúJover, \& GómezGras (2019) on the action and attitude of entrepreneur towards business decision was a fundamental to a new business. Fauchart dan Gruber (2011) that identified three types of entrepreneurial social identities (Darwinian, communitarian, and missionary), have analyzed how these identities influenced the use of cause and effect logic as well as explaining the influence of community's culture in some countries where entrepreneurial initiatives were developing. Based on a survey of 5,076 founders who created their own business, has found that cultural dimension was defined as avoiding uncertainty, individualism, long-term orientation, and the distribution of the influence of power decision carried out by using effluxation. Therefore, students' learning strategy in forming an entrepreneurial spirit can be performed by any effort in learning and practical context.

\section{CONCLUSION}

Based on the results and discussion, this study could conclude that the formation of an entrepreneurial spirit through student's cooperation (KOPMA) has become a place in the formation of an entrepreneurial spirit for students. In addition, 
student's cooperation (KOPMA) has brought some benefits to students. On the other hand, student's learning strategy in forming an entrepreneurial spirit was carried out by dividing time between learning and cooperation activities, the courage to take risks in cooperation and by doing various efforts in learning and practice.

\section{ACKNOWLEDGEMENT}

The author would like to thank Indonesia Education University, Bandung Institute of Technology, Pasundan University, Padjadjaran University that have allowed author and her teams to conduct this research. Alumnus was also expressed to members of student's cooperation (KOPMA) who have agreed to be interviewed.

\section{AUTHOR CONTRIBUTION STATEMENT}

MT, the corresponding author leading for this research processes until the submission process to the targeted journal; AA, helping for methodological processes like confirming the five KOPMAs at four universities and collaborating for interview along with MT and ED; AS, supervising the conceptual framework and results of the research.

\section{REFERENCES}

Abd Majid, N., Zainol, F., Norhayate, W., \& Afthanorhan, A. (2019). Cooperative Entrepreneurship in Malaysian Secondary Schools: A Review of Current Practices, 5, 812-818.

Aini, L. N. (2017). Skripsi: Faktor-faktor yang mempengaruhi partisipasi anggota pada koperasi mahasiswa universitas negeri yogyakarta (kopma uny). Yogyakarta: Jurusan pendidikan ekonomi fakultas ekonomi universitas negeri yogyakarta.

Albert, M.-N., \& Couture, M.-M. (2013). The Support to an Entrepreneur: From Autonomy to Dependence. SAGE Open, 3(2), 2158244013492779. https:// doi.org/10.1177/2158244013492779

Almodóvar-González, M., Fernández-Portillo, A., \& Díaz-Casero, J. C. (2020). Entrepreneurial activity and economic growth. A multi-country analysis. European Research on Management and Business Economics, 26(1), 9-17. https:// doi.org/https:// doi.org/10.1016/j.iedeen.2019.12.004

Anggraeni, D., \& Nurcaya, I. (2016). Peran efikasi diri dalam memediasi pengaruh pendidikan kewirausahaan terhadap niat berwirausaha. E-Jurnal Manajemen.

Arumugam, S., \& Sankaranarayanan, V. (1992). Experiential Learning Model of Entrepreneur Development: An Approach to Develop Innovative Entrepreneurs. Vikalpa, 17(1), 23-29. https:/ / doi.org/10.1177/0256090919920103

Bacq, S., Ofstein, L. F., Kickul, J. R., \& Gundry, L. K. (2016). Perceived entrepreneurial munificence and entrepreneurial intentions: A social cognitive perspective. International Small Business Journal, 35(5), 639-659. https:// doi.org/10.1177/0266242616658943

Bogatyreva, K., Edelman, L. F., Manolova, T. S., Osiyevskyy, O., \& Shirokova, G. (2019). When do entrepreneurial intentions lead to actions? The role of national culture. Journal of Business Research, 96, 309-321. https:// doi.org/https:// doi.org/10.1016/j.jbusres.2018.11.034

Buschow, C., \& Laugemann, R. (2020). What Makes a Media Entrepreneur? Factors Influencing Entrepreneurial Intention of Mass Communication Students. Journalism $\mathcal{E} \quad$ Mass Communication Educator, 1077695820912146. https://doi.org/10.1177/1077695820912146 
Callanan, G. A., \& Zimmerman, M. (2016). To Be or Not To Be an Entrepreneur: Applying a Normative Model to Career Decisions. Journal of Career Development, 43(5), 447-461. https:// doi.org/10.1177/0894845316633525

Cárcamo-Solís, M. de L., Arroyo-López, M. del P., Alvarez-Castañón, L. del C., \& García-López, E. (2017). Developing entrepreneurship in primary schools. The Mexican experience of "My first enterprise: Entrepreneurship by playing." Teaching and Teacher Education, 64, 291-304. https:// doi.org/https:// doi.org/10.1016/j.tate.2017.02.013

Chang, J., \& Rieple, A. (2018). Entrepreneurial decision-making in a microcosm. Management Learning, 49(4), 471-497. https:/ / doi.org/10.1177/1350507618777929

Ciuchta, M. P., Letwin, C., Stevenson, R., McMahon, S., \& Huvaj, M. N. (2017). Betting on the Coachable Entrepreneur: Signaling and Social Exchange in Entrepreneurial Pitches. Entrepreneurship Theory and Practice, 42(6), 860-885. https:// doi.org/10.1177/1042258717725520

Coduras, A., Saiz-Alvarez, J. M., \& Ruiz, J. (2016). Measuring readiness for entrepreneurship: An information tool proposal. Journal of Innovation \& Knowledge, 1(2), 99-108. https:/ / doi.org/https://doi.org/10.1016/j.jik.2016.02.003

Dahl, M. S., Nielsen, J., \& Mojtabai, R. (2010). The effects of becoming an entrepreneur on the use of psychotropics among entrepreneurs and their spouses. Scandinavian Journal of Public Health, 38(8), 857-863. https:/ / doi.org/10.1177/1403494810375490

Dang, C.-M., \& Harima, A. (2020). Dual Embeddedness and Entrepreneurial Activities of Second-Generation Ethnic Entrepreneurs: Multiple Case Studies with Vietnamese Entrepreneurs in Germany. Journal of Entrepreneurship and Innovation in Emerging Economies, 6(1), 84-113. https:/ / doi.org/10.1177/2393957519887554

EstradaCruz, M., VerdúJover, A. J., \& GómezGras, J. M. (2019). The Influence of Culture on the Relationship between the Entrepreneur's Social Identity and Decision-Making: Effectual and Causal Logic. BRQ Business Research Quarterly, 22(4), 226-244. https:// doi.org/10.1016/j.brq.2018.10.002

Farmer, S. M., Yao, X., \& Kung-Mcintyre, K. (2011). The Behavioral Impact of Entrepreneur Identity Aspiration and Prior Entrepreneurial Experience. Entrepreneurship Theory and Practice, 35(2), 245-273. https:// doi.org/10.1111/j.1540-6520.2009.00358.x

Fini, R., \& Toschi, L. (2015). Academic logic and corporate entrepreneurial intentions: A study of the interaction between cognitive and institutional factors in new firms. International Small Business Journal, 34(5), 637-659. https:// doi.org/10.1177/0266242615575760

Fis, A. M., Ozturkcan, S., \& Gur, F. (2019). Being a Woman Entrepreneur in Turkey: Life Role Expectations and Entrepreneurial Self-Efficacy. SAGE Open, 9(2), 2158244019846192. https:// doi.org/10.1177/2158244019846192

Gartner, W. B. (1989). "Who Is an Entrepreneur?" Is the Wrong Question. Entrepreneurship Theory and Practice, 13(4), 47-68. https:// doi.org/10.1177/104225878901300406

Holcomb, T. R., Ireland, R. D., Holmes, R. M., \& Hitt, M. A. (2009). Architecture of Entrepreneurial Learning: Exploring the Link among Heuristics, Knowledge, and Action. Entrepreneurship Theory and Practice, 33(1), 167-192. https:// doi.org/10.1111/j.1540-6520.2008.00285.x

Jayawarna, D., Rouse, J., \& Kitching, J. (2011). Entrepreneur motivations and life course. International Small Business Journal, 31(1), 34-56. https://doi.org/10.1177/0266242611401444 
Kebede, G. F. (2018). Social Capital and Entrepreneurial Outcomes: Evidence from Informal Sector Entrepreneurs in Ethiopia. The Journal of Entrepreneurship, 27(2), 209-242. https:/ / doi.org/10.1177/0971355718781250

Kusumantoro. (2010). Minat Mahasiswa Untuk Menjadi Anggota Koperasi Mahasiswa. Jurnal pendidikan ekonomi dinamika pendidikan, 5(2), 147 - 155.

Lackéus, M. (2015). Enterpreneurship In Education. Paris.

MALAYA, A., Suprihanto, J., \& Kodiran. (2015). Tesis: Peran koperasi mahasiswa (kopma) dalam membangkitkan jiwa kewirausahaan di kalangan mahasiswa dan implikasinya terhadap ketahanan ekonomi anggota (studi di kopma universitas gadjah mada yogyakarta). Yogyakarta: S2 Ketahanan Nasional.

Manimala, M. J., Thomas, P., \& Thomas, P. K. (2019). Perception of Entrepreneurial Ecosystem: Testing the Actor-Observer Bias. The Journal of Entrepreneurship, 28(2), 316-342. https:// doi.org/10.1177/0971355719851908

Martin-Rojas, R., Garcia-Morales, V. J., \& Gonzalez-Alvarez, N. (2019). Technological antecedents of entrepreneurship and its consequences for organizational performance. Technological Forecasting and Social Change, 147, 22-35. https:// doi.org/10.1016/j.techfore.2019.06.018

Mendo-Lázaro, S., León-Del-Barco, B., Felipe-Castaño, E., Polo-Del-Río, M.-I., \& Iglesias-Gallego, D. (2018). Cooperative Team Learning and the Development of Social Skills in Higher Education: The Variables Involved. Frontiers in Psychology, 9, 1536. https://doi.org/10.3389/fpsyg.2018.01536

Moleong, L. J. (2007). Metodologi Penelitian Kualitatif. Bandung: PT Remaja Rosdakarya Offset.

Munawaroh. (2013). The Effect of Type Stad Cooperative Learning Model, the Way of Learning, And Learning Motivation toward Enterpreneurial Attitudes (A case Study in SMK N I Jombang). IOSR Journal of Research \& Method in Education (IOSRJRME), 38-44.

Neroni, J., Meijs, C., Gijselaers, H. J. M., Kirschner, P. A., \& de Groot, R. H. M. (2019). Learning strategies and academic performance in distance education. Learning and Individual Differences, 73 , https:// doi.org/https:// doi.org/10.1016/j.lindif.2019.04.007

Ningrum, M. A. (2017). Peran keluarga dalam menumbuhkan jiwa wirausaha sejak usia dini. Jurnal Pendidikan (Teori dan Praktik). https:// doi.org/10.26740/jp.v2n1.p39-43

Omrane, A., Kammoun, A., \& Seaman, C. (2018). Entrepreneurial Burnout: Causes, Consequences and Way Out. FIIB Business Review, 7(1), 28-42. https:// doi.org/10.1177/2319714518767805

Panda, N. M. (2000). What Brings Entrepreneurial Success in a Developing Region? The Journal of Entrepreneurship, 9(2), 199-212. https://doi.org/10.1177/097135570000900204

Pervaiz, A., \& Khan, M. S. (2015). Entrepreneurial Relations of Pakistani Entrepreneurs: A Macroeconomic and Cultural Perspective. SAGE Open, 5(4), 2158244015607354. https:// doi.org/10.1177/2158244015607354

Phonthanukitithaworn, C., Ketkaew, C., \& Naruetharadhol, P. (2019). Relevant Factors for Success as an Online Entrepreneur in Thailand. SAGE Open, 9(1), 2158244018821757. https://doi.org/10.1177/2158244018821757

Prajapati, K., \& Biswas, S. N. (2011). Effect of Entrepreneur Network and Entrepreneur Self-efficacy on Subjective Performance: A Study of Handicraft and Handloom Cluster. The Journal of Entrepreneurship, 20(2), 227-247. 
https:// doi.org/10.1177/097135571102000204

Rimadani, F., \& Murniawaty, I. (2019). Pengaruh pendidikan kewirausahaan, business center dan kreativitas siswa terhadap jiwa berwirausaha siswa. Economic Education Analysis Journal, 7(4), 976-991. https:// doi.org/10.15294/ eeaj.v7i3.28333

SARI, Z. (2010). Skripsi: Peranan koperasi mahasiswa (kopma) dalam menumbuh kembangkan jiwa kewirausahaan pada anggota koperasi di universitas islam negeri sultan syarif kasim riaU. Pekanbaru: Fakultas Tarbiyah dan Keguruan UIN Sunan Ampel Surabaya.

Srinath, T. T., \& Supriya, M. V. (2009). Entrepreneurial Characteristics and Behaviour Demonstration - A Comparative Study between Small Scale Manufacturing Entrepreneurs and Service Entrepreneurs. Asia Pacific Business Review, 5(1), 56-60. https:// doi.org/10.1177/097324700900500106

St-Jean, É., \& Mathieu, C. (2015). Developing Attitudes Toward an Entrepreneurial Career Through Mentoring: The Mediating Role of Entrepreneurial Self-Efficacy. Journal of Career Development, 42(4), 325-338. https:// doi.org/10.1177/0894845314568190

Sugiyono. (2010). Metode Penelitian Kuantitatif ,kualitatif dan RED. Bandung: Alfabeta.

Thornton, P. H., Ribeiro-Soriano, D., \& Urbano, D. (2011). Socio-cultural factors and entrepreneurial activity: An overview. International Small Business Journal, 29(2), 105-118. https:/ / doi.org/10.1177/0266242610391930

Usman, H., \& Akbar, P. S. (2009). Metodologi Penelitian Sosial. Jakarta: PT Bumi Aksara.

Vladasel, T., Lindquist, M. J., Sol, J., \& van Praag, M. (2020). On the origins of entrepreneurship: Evidence from sibling correlations. Journal of Business Venturing, 106017. https://doi.org/https://doi.org/10.1016/j.jbusvent.2020.106017

Yun, J. J., \& Park, K. (2016). How User Entrepreneurs Succeed: The Role of Entrepreneur's Caliber and Networking Ability in Korean User Entrepreneurship. Science, Technology and Society, 21(3), 391-409. https:// doi.org/10.1177/0971721816661787

Zimnoch, K. (2018). The Role of Student Cooperatives in Education in Poland in the 21st Century. https:// doi.org/10.22616/REEP.2018.031

Zulaihati, S., \& Susanti, S. (2018). Accounting Cooperative System of Business Vocational High School in Jakarta. Budapest International Research and Critics Institute (BIRCI-Journal): Humanities and Social Sciences, 1, 282-288. https:// doi.org/10.33258/birci.v1i4.120

Copyright Holder :

(c) Trihastuti, M., Abdulkarim, A., Danial, E., \& Supriadi, A., (2020).

First Publication Right :

(c) Jurnal Iqra' : Kajian Ilmu Pendidikan

This article is under:

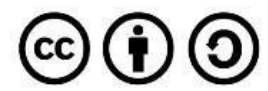

